\title{
Governance for sustainable development: a framework
}

Citation for published version (APA):

van Zeijl-Rozema, A., Cörvers, R., Kemp, R., \& Martens, P. (2008). Governance for sustainable development: a framework. Sustainable Development, 16(6), 410-421. https://doi.org/10.1002/sd.367

Document status and date:

Published: 01/01/2008

DOI:

$10.1002 / \mathrm{sd} .367$

Document Version:

Publisher's PDF, also known as Version of record

Document license:

Taverne

Please check the document version of this publication:

- A submitted manuscript is the version of the article upon submission and before peer-review. There can be important differences between the submitted version and the official published version of record.

People interested in the research are advised to contact the author for the final version of the publication, or visit the DOI to the publisher's website.

- The final author version and the galley proof are versions of the publication after peer review.

- The final published version features the final layout of the paper including the volume, issue and page numbers.

Link to publication

\footnotetext{
General rights rights.

- You may freely distribute the URL identifying the publication in the public portal. please follow below link for the End User Agreement:

www.umlib.nl/taverne-license

Take down policy

If you believe that this document breaches copyright please contact us at:

repository@maastrichtuniversity.nl

providing details and we will investigate your claim.
}

Copyright and moral rights for the publications made accessible in the public portal are retained by the authors and/or other copyright owners and it is a condition of accessing publications that users recognise and abide by the legal requirements associated with these

- Users may download and print one copy of any publication from the public portal for the purpose of private study or research.

- You may not further distribute the material or use it for any profit-making activity or commercial gain

If the publication is distributed under the terms of Article $25 \mathrm{fa}$ of the Dutch Copyright Act, indicated by the "Taverne" license above, 


\title{
Governance for Sustainable Development: A Framework
}

\author{
Annemarie van Zeijl-Rozema ${ }^{1 *}$, Ron Cörvers ${ }^{1,2}$, René Kemp ${ }^{1,3,4}$ and Pim Martens \\ ${ }^{1}$ International Centre for Integrated Assessment and Sustainable Development (ICIS), \\ Maastricht University, The Netherlands \\ ${ }^{2}$ Open University of the Netherlands, Heerlen, The Netherlands \\ ${ }^{3}$ United Nations University - Maastricht Economic and Social Research and Training Centre on Innovation \\ and Technology (UNU-MERIT), The Netherlands \\ ${ }^{4}$ Dutch Research Institute for Transitions (DRIFT), Rotterdam, The Netherlands
}

\begin{abstract}
This paper explores how two complex concepts, governance and sustainable development, can be linked in order to obtain a better understanding of their interactions. We argue that the many perspectives on sustainable development can be mapped on the continuum between ecological sustainability and quality of life. Likewise, the variety of modes of governance can be captured between hierarchical governance and deliberative governance, depending on the degree of involvement of societal actors. From these two typologies we derive a framework for analysis of governance for sustainable development. We realize that the typology is a significant simplification of the complex debates about sustainable development and governance, but it might help scientists and policy makers to explore relevant dimensions of modes of governance for sustainable development and for setting a framework for empirical analysis. The main conclusion of this paper is that the debate on governance for sustainable development will be clarified if the perspective on sustainable development and the mode of governance for achieving it are made more explicit.

Problems that are now exclusively associated with sustainable development might well be problems of governance for sustainable development. Without making explicit what type of governance for sustainable development is pursued, miscommunication between stakeholders and mismatches of the approach with the instruments used could be the result, thus hampering progress in implementing sustainable development. Copyright (C) 2008 John Wiley \& Sons, Ltd and ERP Environment.
\end{abstract}

Received 8 November 2007; revised 11 February 2008; accepted 14 February 2008

Keywords: governance; sustainable development; framework; typology; sustainability strategies; state-society relations/ interactions; multi-actor constellations

*Correspondence to: A. van Zeijl-Rozema, ICIS, PO Box 616, NL-6200 MD Maastricht, The Netherlands. E-mail: a.vanzeijl@icis.unimaas.nl 


\section{Governance for Sustainable Development}

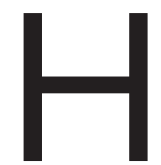

OW CAN SUSTAINABLE DEVELOPMENT BE OPERATIONALIZED? THE CONCEPT OF SUSTAINABLE DEVELOPMENT IS often presented as a pathway to all that is good and desirable in a society. However, this does not help a lot in guiding policy making (Holden and Linnerud, 2007). Often the answer is sought in governance or some collaborative steering by different parties in order to achieve sustainable development. This paper aims at a better understanding of how the combination of various perspectives on sustainable development and different modes of governance creates different strategies for operationalization.

Sustainable development is a complex concept, dealing with different temporal and spatial scales and with multiple stakeholders (Martens, 2006). It indicates a process of changes whereby the development goal is not clearly outlined and is subject to changes throughout the process. In order to deal with sustainable development we need to use a pluralistic approach that can deal with multiple actors and multiple levels, and that is able to help create a common vision on sustainable development and to resolve trade-offs.

Governance is seen as a means to steer the process of sustainable development. However, governance is not a straightforward concept either. It can be seen as a collection of rules, stakeholder involvement and processes to realize a common goal (Kemp and Martens, 2007).

In this paper we assume that sustainable development cannot be achieved without governance because of its nature: to foster common goals by collective action. This strongly relates to the characteristics of the concept of sustainable development:

- in terms of the content: to realize a more sustainable world - most sustainability issues can be seen as wicked problems (ill defined, unstructured), and require a change in thinking, tools and methods that are useful only for simpler ('tame') problems;

- in terms of the process: the involvement of a plurality of parties - most sustainability policies and projects have to deal with social complexity in the sense of the number and diversity of parties involved, and their relations, interactions, beliefs, interests and resources;

- in terms of the context: the institutional setting - most sustainability initiatives are confronted by weak institutionalization, and require structural changes in the dominant institutions.

Wicked problems, social complexity and weak institutionalization undermine the rationale of 'traditional' governing with governments as institutions with hierarchical power, and support the idea of governance as a shared responsibility of representatives from the state, the market and civil society dealing with societal problems.

Now, if we wish to operationalize the idea of 'governance for sustainable development', we have to deal with two important, and mutually coherent characteristics:

- first, we have to accept that there are different perspectives on the concept of sustainable development, ranging from one where ecological limits determine sustainable development, and the concept is objectified based on scientific evidence, to a more divergent one where many possible goals co-exist and societal preferences and uncertainties shape the concept;

- second, we have to be aware that multiple modes of governance are possible to steer the process of sustainable development, ranging from a more or less top down approach and hierarchical relations between the government and other actors in society to bottom up approaches and horizontal relations between all actors involved.

Let us first have a closer look at various perspectives on sustainable development and different modes of governance.

\section{Perspectives on Sustainable Development}

Sustainable development is not a single, well defined concept and various positions and perspectives exist. Hueting and Reijnders (2004) argue that sustainability is defined by ecological boundaries that can be scientifically determined. McCool and Stankey (2004), however, stress that the question of what is to be sustained is a societal one and therefore at once both a technical as well as a normative decision. Gibson (200I) points to the normativity of 
the sustainable development perspective because it includes society and societal development. Brand and Karvonen (2007) argue that sustainability is also locally specific and more a matter of local interpretation than of the setting of objective or universal goals. The UK government relates sustainable development to quality of life and well-being (DEFRA, 2005). In Bhutan the development strategy is guided by the philosophy of 'Gross National Happiness' based on sustainable and equitable economic growth, ecological and cultural preservation and good governance (Rinzin et al., 2007). Williams and Millington (2004) distinguish between stronger sustainability, in which the importance of a change in values and behaviour is stressed, and weaker sustainability, with its faith in technical solutions.

From this short overview we learn that there are different views on sustainable development. Whichever view is propagated, it entails a normative choice: a choice for giving priority either to ecological concerns or to societal concerns. Besides, it is often understood that there has been an evolution of the concept over time from the early focus on the environmental dimension towards the current understanding that sustainable development is a process that integrates economical, environmental and societal objectives (UNDESA, 200I). Without making judgement, we place on one end of the continuum sustainable development as a concept related to ecological limits for growth that is based on scientific evidence and that can be objectified by using science-based criteria and indicators. On the other end sustainable development is seen as a normative and fuzzy concept related to well-being and quality of life, that is context dependent and a result of societal preferences, and that allows for many divergent opinions to co-exist. In our discussion we therefore distinguish between an ecological sustainability perspective and a well-being perspective on sustainable development (see the next section for more details). However, we acknowledge the many mixed forms that currently exist. When we think of the UK's sustainable development strategy Securing the Future (DEFRA, 2005), the definition used ${ }^{\mathrm{I}}$ has a strong emphasis on quality of life. At the same time the strategy states 'This (pursuing the goal of sustainable development, AvZR) will be done in ways that protect and enhance the physical and natural environment, and use resources and energy as efficiently as possible', which is a clear indication of ecological sustainability.

With our typology we hope to better understand the different perspectives on sustainable development that exist. Williams and Millington (2004) have provided a heuristic framework for understanding the diverse and contested meanings of sustainable development. We go one step further and provide a framework that combines understanding of sustainable development with possible governance strategies for operationalization.

\section{Modes of Governance}

Different views on sustainable development may lead to different governance approaches. The term governance represents the notion of steering, and can be seen as a shared responsibility of representatives from the state, the market and civil society dealing with societal problems (Glasbergen and Driessen, 2002). When talking about governance we generally accept that the state no longer has the necessary authority or means to produce a (political) position that adequately represents the general or collective interest (Lamy and Laidi, 2002). Various scholars have made a classification of different modes of governance. Kooiman (2003) distinguishes between hierarchical, co- and self-governance, ranging from dominance of one actor (often the state) over other actors to social-political autonomy of all actors. In the NewGov project researchers see different modes of governance depending on the level of state or public actor involvement. This can range from hierarchical to non-hierarchical coordination (Börzel, 2006; Börzel et al., 2005), from public authority towards societal autonomy (Treib et al., 2005) or from hierarchy towards heterarchy (Smismans, 2006). At all levels, from local to transnational, we see a movement away from 'traditional' governing with governments as institutions with hierarchical power, towards governance as a shared responsibility of public and private actors. Swyngedouw (2005) calls this governance-beyond-the-state and defines it as horizontal networks of private (market), civil society (usually NGOs) and state actors. Finally, governancewithout-the-state is also possible. This is the case in fragile or weak states where governance arises because people have common interests and they cannot rely on the state to help them.

${ }^{\text {I }}$ The goal of sustainable development is to enable all people throughout the world to satisfy their basic needs and to enjoy a better quality of life, without compromising the quality of life for future generations. 
From this short overview we conclude that different modes of governance are possible and are seen to exist on a continuum (Börzel et al., 2005; Kooiman, 2003; Treib et al., 2005). We would, therefore, like to propose two modes of governance as the points between which most modes of governance for sustainable development can be captured: hierarchical governance - which is not dissimilar to traditional governing - and deliberative governance - in which societal actors shape societal goals through dialogue and social learning. We will explain these in more detail below.

\section{Conceptual Framework}

In the following we first characterize the perspectives on sustainable development and modes of governance that were identified in the previous paragraph. Then we combine the perspectives and modes into a conceptual framework for analysing governance for sustainable development. Subsequently, we discuss the views of several scholars on the matter, and place them in the framework. Finally, we provide some examples for each combination.

In the previous paragraph we distinguish between an ecological sustainability perspective on sustainable development and a well-being perspective. Within the ecological sustainability perspective sustainable development is seen as an issue of development within the ecological boundaries and carrying capacity of the planet. It is something that can be measured and that is based on scientific evidence. Some characteristics are

- focus on environment

- based on scientific evidence

- objectively measurable.

The well-being perspective on sustainable development conceptualizes sustainable development as a quality of life issue (in an intertemporal sense) rather than an environmental issue. It looks at environment as far as it concerns well-being, either directly through life-supporting functions and amenities and indirectly through offering resources for the economic process and assimilating waste. Some characteristics are

- focus on all three pillars of sustainable development

- diverse opinions co-exist

- result of societal preferences

- contextually determined.

We argue that the various classifications of governance can be distinguished between the extremes of hierarchical governance and deliberative governance. The nature of hierarchical governance is a top down approach and vertical relations between a lead actor and other actors in society. In this strategy the lead actor, often government, is the most important player that decides and holds power. Some characteristics are

- decision-making by the lead actor

- vertical relation between lead actor and other societal actors

- planning and control.

In deliberative governance we see bottom up approaches and horizontal relations between all actors involved. The principle of this strategy is that all parties (state, market and civil society) share their powers and operate on an equal footing in an open deliberative way. Some characteristics are

- decision-making by multiple actors

- horizontal relations between actors

- network management.

Furthermore, we can distinguish several characteristics that are neither pure governance characteristics nor characteristics purely related to a certain perspective on sustainable development, but that are expressions of governance for sustainable development. We will discuss issues such as implementation strategy, commitment, uncertainty, focus, role for technical fixes, and monitoring and evaluation, also see Table 2. 
- The implementation strategy that is used in governance for sustainable development depends on both the mode of governance and the perspective on sustainable development. An ecological sustainability perspective with a hierarchical mode of governance might lead to a clear plan of implementation with little discretion for the means to achieve it.

- It is often said that without commitment throughout society sustainable development will not happen easily. Different types of governance for sustainable development will invoke this commitment to a greater or lesser extent.

- Uncertainty is always an issue in sustainable development. Systems are poorly understood and forecasts for the future have large error margins. Dealing with uncertainty depends on where it is perceived and who feels responsible. This varies with the type of governance for sustainable development.

- Depending on the governance mode and the perspective on sustainable development the focus is different. The focus can lie on the output, i.e. achieving the clearly defined goal sustainable development. Sometimes the focus will be on the process of goal-setting and the search towards sustainable development.

- Technical fixes or technical solutions are one component of achieving sustainable development. They are currently widely used. Another component is behavioural change and system innovation, which needs strong societal support to be successful. They are applied less often and are not considered an option in hierarchical systems unless benefits are clear for society.

- Each type of governance for sustainable development has implications for the monitoring and evaluation criteria.

When combining the perspectives on sustainable development with the modes of governance, we propose the following conceptual framework (Figure I), which captures within its boundaries existing efforts and theories regarding governance for sustainable development. Obviously, a typology as we propose is a significant simplification of the complex debates about the 'real' meaning of sustainable development and the huge variety in forms of governance that we see around the world. However, the aim of this typology is to take a first step in the establishment of a framework that helps scientists and policy makers to explore relevant dimensions of modes of governance for sustainable development and for setting a framework for empirical analysis.

\section{The Ecological Sustainability-Hierarchical Type}

Decisions are taken by the leading actor, often government. A vertical relation exists between the leading actor and other actors in society. Sustainable development is seen as a goal that can be objectified based on scientific evidence. Goal-setting is done to a large extent by the leading actor; consensus exists that development should take place within ecological limits.

Implementation of the sustainable development goal is decided upon by the leading actor in a straightforward process with little discretion for those implementing it. Solutions are mainly sought in the domain of technical fixes. Other actors are not necessarily committed to sustainable development but they follow the leader. The focus in this type is on goal achievement. Monitoring and evaluation indicators will be output oriented.

A possible danger in this system is over-simplification and concentration on remedying a few symptoms such as reducing $\mathrm{CO}_{2}$ levels. By ignoring inter-linkages that are so important in sustainable development, society might be surprised by unwanted side-effects and a transfer of problems and could find itself unable to cope with it.

\section{Views and Examples}

An example of an ecological sustainability perspective on sustainable development can be found in the work of Hueting and Reijnders (2004). They state that 'long-term sustainability of society can as far as the physical environment is concerned, only be based on physical standards'. They argue that indicators for sustainable development aggregating the three aspects of sustainable development are often not meaningful. Also, involving societal actors in the construction of what sustainability is, and thus of what sustainable development indicators should be, is not meaningful. Constructing sustainability indicators 'is a matter of proper division of labour between the sciences'. 


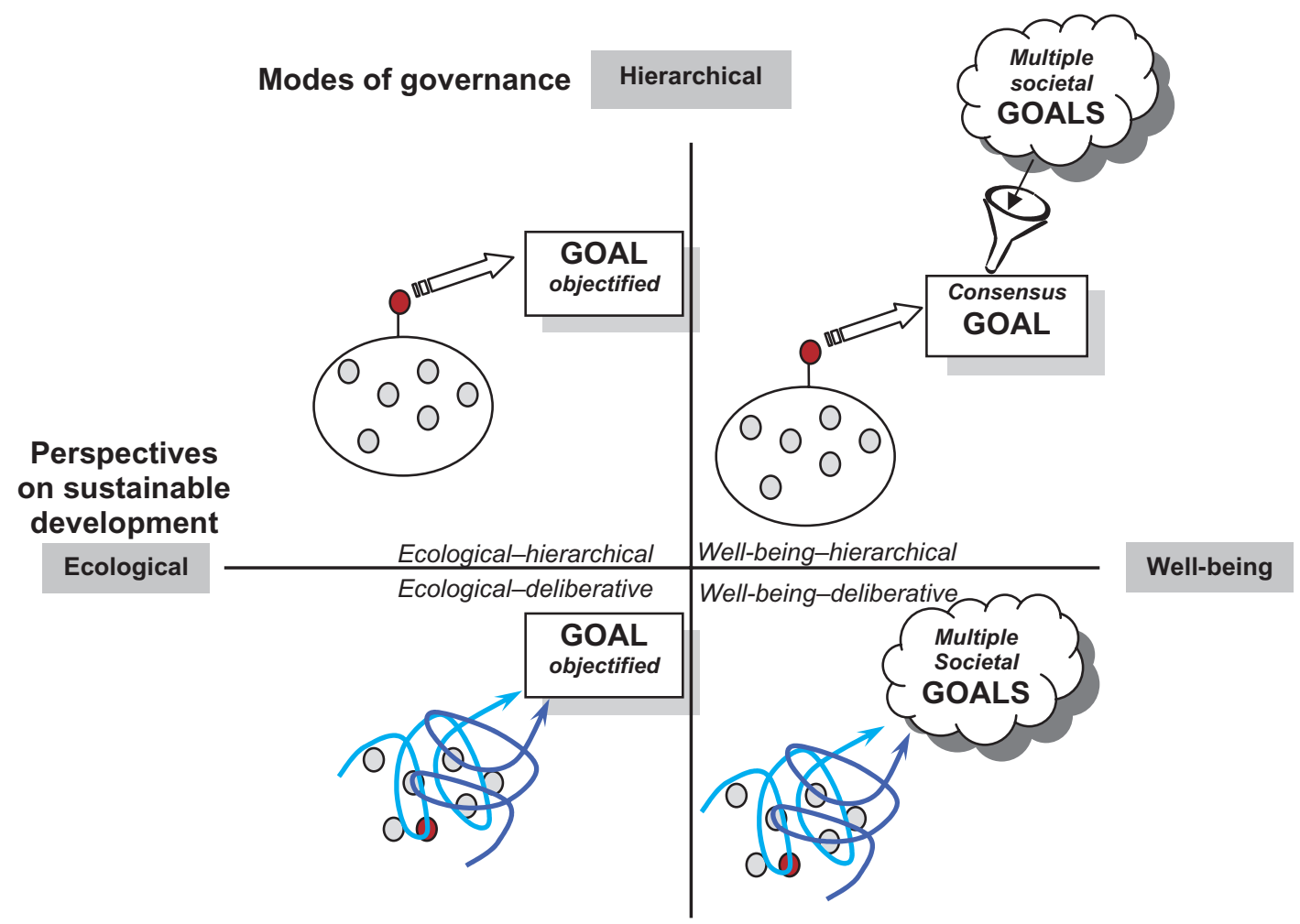

Deliberative

Leading actor

Other actors (market and society)

Figure 1. Conceptual framework of governance for sustainable development

An example is the Kyoto protocol and its aim to reduce the output of greenhouse gases. The goals are set by governments, and should be achieved by society within a given timeframe. Both goal and implementation are set by the leading actor.

An instrument that fits an output-oriented approach is cost effectiveness analysis. CEA shows in monetary terms which options are best.

\section{The Ecological Sustainability-Deliberative Type}

Representatives of the state, market and civil society decide on how best to achieve the goal of sustainable development. The goal is objectified with the help of scientific findings. Therefore, it is easier to reach consensus. Actors agree that development should take place within ecological limits. Thus, the main issue is how to get to these goals. Actors decide on the best or most wanted solutions by negotiation and learning by doing. In the science based society there is an important role for technical solutions. We see horizontal relations between the government and other actors in society in the form of networks. There is mutual interdependence between the actors involved. A deliberative approach is followed to achieve the clear goal of sustainable development. Adaptive policy is important for finding the road towards the goal, as negotiation or learning lead to new insights (Rammel and van den Bergh, 2002).

As goals are rather clear, the main focus lies on possible roads towards achieving the goals. There is a high degree of discretion regarding the implementation. Diversity in solutions is accepted. However, there is some 
uncertainty regarding the best way to achieve sustainable development. Therefore, monitoring and evaluation will focus both on goal achievement and on finding out more about good solutions, i.e. the problem-solving process. Knowledge on and commitment to sustainable development is widely present at the implementation level, but not so much at the level of the sustainable development concept, which is the domain of science.

The emphasis on ecology might be insufficient to understand the complexities of achieving sustainable development. However, the implementation process will reveal the problems. Still, the strong focus on technology could prevent society from exploring system innovations.

\section{Views and Examples}

Brand and Karvonen (2007) dub the technocratic, expert-dominated way of looking at sustainable development the 'technical fix approach to sustainable development'. They state that 'today, the technical fix approach in sustainable development is the dominant model in industrialized countries because it retains the existing power of political and economic elites'. They show that the dominance of science and technology as described above is a legitimate danger in their quote of Dryzek (I997, in Brand and Karvonen, 2007): 'in its most limited sense, ecological modernization looks like a discourse for engineers and accountants'. Finally, Brand and Karvonen argue that the technocratic approach to sustainable development should not be abandoned but should be directed by society as a whole. Different types of expertise, including that of the non-experts (i.e. civil society), are all complementary and necessary. In conclusion, they criticize the rational problem solving way being proposed as the road towards sustainable development.

An instrument that could be used by this type of governance for sustainable development is multi-criterion analysis, in which weights are used for arriving at an overall evaluation of a sustainable development action. Many different solutions to sustainable development can be evaluated and the best ones will be selected based on certain criteria.

An example of the ecological sustainability-deliberative type is the work of the Intergovernmental Panel on Climate Change (IPCC) and the Millennium Ecosystem Assessment. The goal is clear, but implementation is left to the discretion of the signatories.

\section{The Well-Being-Hierarchical Type}

The ultimate goal of sustainable development is not well defined. It is seen as the result of societal preferences and is related to well-being and the quality of life. Uncertainty regarding priorities dominates the goal-setting process. The leading actor (often government) draws upon society in the goal-setting process. From among the diverging opinions, a consensus perspective is sought by the leading actor from the variety of priorities, and for the sake of implementation one goal is chosen. The leading actor recognizes that goal-setting is driven by the societal context. Therefore, the goal can change. However, once the sustainable development goal is clarified, the leading actor coordinates and steers the road towards sustainable development. Technical fixes, as well as behavioural change and system innovation, play an important role.

Some discretion exists in the implementation strategy. The focus lies on the goal-setting process and on goal achievement. Society participates in the goal-setting process. Commitment to sustainable development is present, but not always for the policies formulated at the top. Monitoring and evaluation of this type of governance for sustainable development deals mainly with goal achievement and investigation of changed preferences that would oblige the leading actor to adjust the sustainable development goals.

A possible danger in this system is that societal actors could be unwilling to follow the path chosen for them. Furthermore, we see tension between the uncertainty in the sustainable development priorities and the linear approach taken by the leading actor.

\section{Views and Examples}

Bell and Morse (2005) observe that although sustainable development is often seen as a circular and boundless concept, its implementation is often surprisingly linear. Once goals are defined, a strategy or project document is 
drawn up, budget is allocated and the programme is implemented. Often blueprint projects are designed that require clarity on outputs prior to inception. They state that the awareness of the journey throughout the project should be part of project planning, and a formal structure in projects is needed that facilitates debate and learning (Bell and Morse, 2005).

Cost-benefit analysis fits with a well-being-hierarchical perspective, in which enhanced well-being is the goal to be achieved through authoritarian decision-making.

\section{The Well-Being-Deliberative Type}

Representatives of the state, market and civil society deliberate on the priorities for sustainable development and about the way to pursue the desired goals of well-being and quality of life. There are horizontal relations between the government and other actors in society. There is attention to a multitude of (soft) goals and the trade-offs between them. Goal-setting depends on the societal context. The process of defining the goals, taking action towards implementation, reframing the goals and adjusting the road towards them is an unfolding societal process dependent on learning by doing and negotiation. The co-existence of many goals is accepted and the end-point is not known in advance. Society evolves and thus the sustainable development context changes. Uncertainty in goals and implementation is overcome by deliberation and learning. Adaptive policy is vital (Bagheri and Hjorth, 2007; Kemp et al., 2007; Rammel and van den Bergh, 2002).

Here governance for sustainable development is not viewed as the way to get to predefined goals and outcomes but as an open, deliberative process that helps to articulate what is wanted and desirable. It is accepted that there are different ideas of what sustainable development means for actors in various sectors, that solutions tend to be sustainable within these sectors rather than across the whole of society, that new developments bring new risks that cannot be anticipated, that sustainable development is a long-term, open-ended project that precedes and supersedes limited-term, democratically elected governments and, finally, that it involves making choices and perhaps trade-off decisions on highly contested issues (Farrell et al., 2005). Technical fixes play a minor role. In general context-sensitive solutions are sought, including behavioural change and system innovation. Commitment to sustainable development is found throughout society. The process towards sustainable development is more important than achieving a pre-defined goal. Monitoring and evaluation will be focused on the process and on how to deal with new insights.

A drawback in this type is that uncertainty in goals and processes make it difficult to set the priorities and decide on implementation. Society might be blocked from taking action by indecisiveness.

\section{Views and Examples}

Voß et al. (2006) propose reflexive governance as an answer to dealing with sustainable development. A characteristic of reflexive governance is that it understands itself to be part of the dynamics which are governed. Broader dynamics, which are not usually considered to be part of governance, are acknowledged to also play an important role in shaping societal development and therefore become part of governing (e.g. science, public discourse, social networking, technological development). Reflexive governance acknowledges that governing activities are entangled in wider societal feedback loops and are partly shaped by the (side-) effects of its own working.

An example of a tool used in this type could be 'transition management'. Transition management is a forwardlooking and adaptive model for steering societal change towards sustainable development goals with a great orientation towards system innovation. Transition management is a new steering concept that relies on 'Darwinistic' evolutionary processes of guided variation and selection instead of planning. Industrial interests in sustainable development are being exploited through innovation policy. Different trajectories are explored and flexibility is maintained, which is exactly what a manager would do when faced with great uncertainty and complexity. It is being used in the Netherlands as a model for sustainable development, for which see the articles on the Dutch energy transition (Kemp and Loorbach, 2005; Loorbach and Kemp, 2007).

Table I provides a summary overview of the characteristics of the four main types of governance for sustainable development as discussed in this paper. 


\begin{tabular}{|c|c|c|c|c|}
\hline $\begin{array}{l}\text { Characteristics of } \\
\text { Governance for } \\
\text { Sustainable } \\
\text { Development }\end{array}$ & Ecological-Hierarchical & Ecological-Deliberative & Well-being-Hierarchical & Well-being-Deliberative \\
\hline $\begin{array}{l}\text { Perspective on } \\
\text { Sustainable } \\
\text { Development }\end{array}$ & Ecological & Ecological & Well-being & Well-being \\
\hline Use of Goals & $\begin{array}{l}\text { Reliance on quantitative } \\
\text { goals }\end{array}$ & $\begin{array}{l}\text { Both qualitative and } \\
\text { quantitative goals } \\
\text { important }\end{array}$ & $\begin{array}{l}\text { Attention to multitude } \\
\text { of goals and their } \\
\text { tradeoffs }\end{array}$ & $\begin{array}{l}\text { Attention to multitude } \\
\text { of goals and their } \\
\text { tradeoffs }\end{array}$ \\
\hline $\begin{array}{l}\text { Mode of } \\
\text { Governance }\end{array}$ & Hierarchical & Deliberative & Hierarchical & Deliberative \\
\hline Key decision-maker & $\begin{array}{l}\text { Central government, } \\
\text { president in } \\
\text { authoritarian regimes }\end{array}$ & $\begin{array}{l}\text { Multiple actors, including } \\
\text { local government } \\
\text { and NGOs }\end{array}$ & $\begin{array}{l}\text { National politics and/or } \\
\text { local government }\end{array}$ & $\begin{array}{l}\text { Multiple actors, with } \\
\text { a special role for } \\
\text { civil society }\end{array}$ \\
\hline $\begin{array}{l}\text { Stakeholder } \\
\text { relations }\end{array}$ & Vertical, top-down & Horizontal, bottom-up & Vertical, top-down & $\begin{array}{l}\text { Horizontal, bottom-up, } \\
\text { dynamically linked up } \\
\text { with top-down }\end{array}$ \\
\hline Tools for use ${ }^{a}$ & Cost effectiveness analysis & $\begin{array}{l}\text { Multi-criteria analysis such } \\
\text { as weighted summation }\end{array}$ & $\begin{array}{l}\text { Cost-Benefit Analysis for } \\
\text { implementation }\end{array}$ & $\begin{array}{l}\text { Integrated sustainability } \\
\text { assessment; } \\
\text { Participatory tools } \\
\text { such as focus groups/ } \\
\text { consensus conference } \\
\text { for the goal-setting. }\end{array}$ \\
\hline Examples & Kyoto protocol & $\begin{array}{l}\text { IPCC/Millennium } \\
\text { Ecosystem Assessment }\end{array}$ & Millennium goals & $\begin{array}{l}\text { Dutch energy transition } \\
\text { policy based on } \\
\text { transition arenas for } \\
\text { system innovation }\end{array}$ \\
\hline
\end{tabular}

Table 1. Characteristics of various types of governance for sustainable development

${ }^{a}$ The tools may be used implicitly rather than explicitly. 


\begin{tabular}{|c|c|c|c|c|}
\hline $\begin{array}{l}\text { Expression of } \\
\text { Governance for } \\
\text { Sustainable } \\
\text { Development }\end{array}$ & $\begin{array}{l}\text { Ecological- } \\
\text { Hierarchical }\end{array}$ & $\begin{array}{l}\text { Ecological- } \\
\text { Deliberative }\end{array}$ & Well-being-Hierarchical & Well-being-Deliberative \\
\hline SD goal (summary) & $\begin{array}{l}\text { SD goals are defined } \\
\text { by leading } \\
\text { authorative actor } \\
\text { using scientific } \\
\text { evidence. Specific } \\
\text { goals are not an } \\
\text { issue for societal } \\
\text { discussion }\end{array}$ & $\begin{array}{l}\text { SD goals } \\
\text { (mostly about } \\
\text { environmental } \\
\text { issues) are defined } \\
\text { by multiple actors, } \\
\text { drawing on } \\
\text { scientific evidence. }\end{array}$ & $\begin{array}{l}\text { SD goals constitute } \\
\text { temporary consensus } \\
\text { of various societal } \\
\text { preferences and are } \\
\text { finally set by leading } \\
\text { actor. Need for } \\
\text { revision as society } \\
\text { changes is understood } \\
\text { and accepted }\end{array}$ & $\begin{array}{l}\text { Multitude of SD goals are } \\
\text { defined by multiple actors. } \\
\text { There is agreement on } \\
\text { their diversity and there is } \\
\text { a need for refining and } \\
\text { revising the understanding } \\
\text { of the concept. Space for } \\
\text { diverse ideas and } \\
\text { strategies }\end{array}$ \\
\hline Commitment & $\begin{array}{l}\text { Commitment to the } \\
\text { rules set by leading } \\
\text { actor, not to } \\
\text { sustainable } \\
\text { development }\end{array}$ & $\begin{array}{l}\text { Commitment to SD at } \\
\text { the implementation } \\
\text { level }\end{array}$ & $\begin{array}{l}\text { Commitment to SD but } \\
\text { not always to the } \\
\text { policies formulated } \\
\text { from the top. }\end{array}$ & $\begin{array}{l}\text { Commitment to SD } \\
\text { throughout society, } \\
\text { includes thinking about } \\
\text { the concept as well as } \\
\text { realising implementation }\end{array}$ \\
\hline $\begin{array}{l}\text { Acknowledgement of } \\
\text { uncertainty }\end{array}$ & $\begin{array}{l}\text { Uncertainty about } \\
\text { scientific evidence } \\
\text { and policy effects is } \\
\text { downplayed }\end{array}$ & $\begin{array}{l}\text { Uncertainty is } \\
\text { acknowledged and } \\
\text { policy concentrates } \\
\text { on the best ways to } \\
\text { achieve the goal }\end{array}$ & $\begin{array}{l}\text { Uncertainty is } \\
\text { concentrated on the } \\
\text { concept of SD. One is } \\
\text { willing to act in the } \\
\text { face of uncertainty. }\end{array}$ & $\begin{array}{l}\text { Uncertainty about the } \\
\text { concept of SD and } \\
\text { the best ways to achieve } \\
\text { the goal is openly } \\
\text { acknowledged. Policies } \\
\text { are seen as fallible }\end{array}$ \\
\hline $\begin{array}{l}\text { Monitoring and } \\
\text { evaluation questions }\end{array}$ & $\begin{array}{l}\text { Has SD goal been } \\
\text { achieved? }\end{array}$ & $\begin{array}{l}\text { Has SD goal been } \\
\text { achieved and what } \\
\text { solutions have been } \\
\text { developed? }\end{array}$ & $\begin{array}{l}\text { Has SD goal been } \\
\text { achieved? Has } \\
\text { consensus goal } \\
\text { changed and should } \\
\text { implementation } \\
\text { change? }\end{array}$ & $\begin{array}{l}\text { Are we on the right track? } \\
\text { What are the latest views } \\
\text { on SD? What are possible } \\
\text { ways to achieve SD? }\end{array}$ \\
\hline
\end{tabular}

Table 2. Expressions of governance for sustainable development, for various typologies

\section{Conclusions}

In this paper we assume that sustainable development cannot be achieved without governance because of its nature: it is normative and requires collective action. We argue that the many perspectives on sustainable development can be described meaningfully between the extremes of the ecological sustainability perspective and the well- 
being perspective. The variety of modes of governance can be captured between hierarchical governance and deliberative governance. From this we derive four ideal types of governance for sustainable development.

The typology does not account for all the complexities that we may observe in society: national government is likely to be committed to both well-being and to environmental protection, as is local government; they may act in an authoritarian manner or a more reflexive manner in different cases. In the formulation of sustainable development strategies and goals they may rely on deliberative processes with key actors, involving business and civil society organizations, and overruling other societal actors.

Our typology seeks to explore relevant dimensions of governance for sustainable development, to prepare the ground for empirical research into operationalization of sustainable development.

It is possible that we find that the typology is too crude and that the modes of governance for sustainable development are more diverse than our framework can handle. However, we believe that the typology serves a useful role for discussion and for opening up a new trajectory for research into understanding and improving operationalization of sustainable development. One could think of the analysis of governance for sustainable development within nations and across nations and domains. With the framework we may be able to map the evolution of modes of governance for sustainable development and their accompanying processes and instruments, or one could think of mapping the various modes of governance for sustainable development within one case. We might also follow governance for sustainable development over time, or identify the matches and mismatches of processes, governance instruments and perspectives on sustainable development at various stages of the operationalization process.

The framework may thus be used to identify the method in the madness: it has the potential to structure and facilitate governance for sustainable development, as it provides leverage points for an evaluation of the effects of sustainable policy and the design of possible solutions through sustainable strategies. In the near future, we will use the framework to analyse several regional case studies on governance for sustainable development and we strongly hope that others will do likewise.

\section{Acknowledgement}

The authors are indebted to the Province of Limburg for their grant to the project 'Governance for sustainable development; the case of Limburg, The Netherlands'.

\section{References}

Bagheri A, Hjorth P. 2007. Planning for sustainable development: a paradigm shift towards a process-based approach. Sustainable Development I5: $83-96$.

Bell S, Morse S. 2005. Delivering sustainability therapy in sustainable development projects. Journal of Environmental Management 75: $37-5 \mathrm{I}$. Börzel TA. 2006. Interim Report. New Modes of Governance and Enlargement; When Theory Meets Reality, NewGov project.

Börzel TA, Guttenbrunner S, Seper S. 2005. Conceptualizing New Modes of Governance in EU Enlargement, NewGov project.

Brand R, Karvonen A. 2007. The ecosystem of expertise: complementary knowledges for sustainable development. Sustainability: Science, Practice and Policy 3: 2I-3I.

DEFRA. 2005. Securing the Future: The UK Government Sustainable Development Strategy. DEFRA; I-I86.

Dolan P, Peasgood T, Dixon A, Knight M, Philips D, Tsuchiya A, White M. 2006. Research on the Relationship Between Well-Being and Sustainable Development. DEFRA; I-52.

Farrell K, Kemp R, Hinterberger F, Rammel C, Ziegler R. 2005. From *for* to Governance for Sustainable Development in Europe - what is at stake for further research. International Journal of Sustainable Development 8: I27-I50.

Gibson RB. 200I. Specification of Sustainability-Based Environmental Assessment Decision Criteria and Implications for Determining 'Significance' in Environmental Assessment, Report. 46, Canadian Environmental Assessment Agency Research and Development Programme.

Glasbergen P, Driessen PPJ. 2002. The paradigm shift in environmental politics. In Greening Society, the Paradigm Shift in Dutch Environmental Policies, Driessen PPJ, Glasbergen P (eds). Kluwer: Dordrecht; 3-26.

Holden E, Linnerud K. 2007. The sustainable development area: satisfying basic needs and safeguarding ecological sustainability. Sustainable Development I5: 174-187.

Hueting R, Reijnders L. 2004. Broad sustainability contra sustainability: the proper construction of sustainability indicators. Ecological Economics 50: $249-260$. 
Kemp R, Loorbach D. 2005. Dutch policies to manage the transition to sustainable energy. In Jahrbuch Ökologische Ökonomik 4, Innovationen und Nachhaltigkeit, Beckenbach F, Hampicke U, Leipert C, Meran G, Minsch J, Nutzinger HG, Pfriem R, Weimann J, Wirl F, Witt U (eds). Metropolis: Marburg; 123-150.

Kemp R, Loorbach D, Rotmans J. 2007. Transition management as a model for managing processes of co-evolution towards sustainable development. In Special Issue on (Co)-Evolutionary Approach to Sustainable Development, The International Journal of Sustainable Development and World Ecology 78-9I.

Kemp R, Martens P. 2007. Sustainable development: how to manage something that is subjective and can never be achieved? Sustainability: Science, Practice and Policy 3: I-IO.

Kooiman J. 2003. Governing as Governance. London: Sage.

Lamy P, Laidi Z. 2002. A European approach to global governance. Progressive Politics: I-I3.

Loorbach D, Kemp R. 2007. Transition management for the Dutch energy transition: the multilevel governance aspects. In Managing the Transition towards Renewable Energy; Theory and Practice from Local, Regional and Macro Perspectives, van den Bergh JCJM, Bruinsma FR (eds). Elgar: Cheltenham; 243-264.

Martens P. 2006. Sustainability: science or fiction? Sustainability: Science, Practice and Policy 2: I-5.

McCool SF, Stankey GH. 2004. Indicators of sustainability: challenges and opportunities at the interface of science and policy. Environmental Management 33: 294-305.

Rammel C, van den Bergh J. 2002. An evolutionary perspective on sustainable development policies: adaptive flexibility and risk minimising. Ecological Economics 47: I2I-I33.

Rinzin C, Vermeulen WJV, Glasbergen P. 2007. Public perceptions of Bhutan's approach to sustainable development in practice. Sustainable Development I5: 52-68.

Smismans S. 2006. New Modes of Governance and the Participatory Myth, Report N-o6-oI, European Governance Papers.

Swyngedouw E. 2005. Governance innovation and the citizen: the Janus face of governance-beyond-the-state. Urban Studies 42: I99I-2006.

Treib O, Bähr H, Falkner G. 2005. Modes of Governance: a Note Towards Conceptual Clarification, Report N-05-02, European Governance Papers.

UNDESA. 200I. Guidance in Preparing a National Sustainable Development Strategy: Managing Sustainable Development in the New Millennium, Report DESA/DSD/PC2/BPi3.

Voß J-P, Bauknecht D, Kemp R. 2006. Preface. In Reflexive Governance for Sustainable Development, Voß J-P, Bauknecht D, Kemp R (eds). Elgar: Cheltenham; xiv-xvii.

Williams CC, Millington AC. 2004. The diverse and contested meanings of sustainable development. The Geographical Journal I70: 99-I04. 